\title{
Optimalisasi Pengenalan Produk Unggulan Desa Melalui Pelatihan Website Promosi Kecamatan Patuk Gunungkidul
}

\author{
Astika Ayuningtyas*1, Yuliani Indrianingsih ${ }^{2}$, Uyuunul Mauidzoh ${ }^{3}$ \\ 1,2Program Studi Teknik Informatika, ${ }^{3}$ Program Studi Teknik Industri \\ 1,2,3Sekolah Tinggi Teknologi Adisutjipto \\ *e-mail: astika@stta.ac.id ${ }^{1}$,yuulistta@gmail.com ${ }^{2}{ }_{2}$ farahzizy@gmail.com $^{3}$
}

\begin{abstract}
The development of information and computerized tenology has led to what is called the Internet and the World Wide Web (WWW). In addition, the dramatic development of the Internet has given users more choice and control over content, and also provides individuals, businesses, and public and private organizations with the opportunity to generate and disseminate information. The interactive features of the web can be an effective way to build and maintain mutually beneficial relationships if the web is used properly. The presence of the Internet has proven to have a positive impact on the development of a village, sub-district or district to introduce and inform the potential of its region. This is evident in several regions of Indonesia which have successfully used Internet facilities to introduce tourist destinations to the world. Therefore, the training on the promotion website is an effort to optimize the introduction of high quality village products in the district of Patuk and is also intended to follow the results of research on the design of a promotion of superior products and tourist objects on the web in Patuk Gunungkidul district. On the basis of the website promotion feasibility test during the training for each representative in 11 villages in the Patuk sub-district, 87.36\% was obtained, so that it can be said that the Introduction of superior village products via promotional materials based on the website was optimal and met the needs of users.
\end{abstract}

Keywords: website, training, promotion, featured product

\begin{abstract}
Abstrak
Perkembangan tenologi informasi dan komputerisasi telah memunculkan apa yang dikenal sebagai internet dan World Wide Web (WWW). Selain itu, perkembangan internetyang spektakuler telah memberikan lebih banyak pilihan dan kontrol atas isi bagi pengguna dan juga menawarkan kesempatan kepada individu, perusahaan dan organisasi publik serta swasta untuk memproduksi dan menyebarkan informasi. Karaktersitik interaktif dari Web dapat menjadi sarana yang efektif untuk membangun dan memelihara hubungan yang saling menguntungkan jika Web digunakan dengan benar. Hadirnya internet, ternyata berdampak positif bagi perkembangan suatu desa, kecamatan atau kabupaten untuk memperkenalkan, menginformasikan potensi daerah yang dimilikinya. Hal ini terbukti dari beberapa daerah di Indonesia yang telah berhasil memanfaatkan fasilitas internet untuk memperkenalkan destinasi wisata kepada dunia. Oleh sebab itu, pelatihan Website promosi sebagai upaya untuk mengoptimalisasi pengenalan produk unggulan desa di Kecamatan Patuk dan juga sekaligus dimaksudkan untuk menindaklanjuti hasil penelitian tentang rancang bangun promosi produk unggulan dan obyek wisata berbasis Web di Kecamatan Patuk Gunungkidul. Berdasarkan uji kelayakan Website promosi pada saat pelatihan kepada setiap perwakilan di 11 Desa Kecamatan Patuk diperoleh 87,36 \%, sehingga dapat dinyatakan bahwa pengenalan produk unggulan desa melalui media promosi berbasis Website telah optimal dan memenuhi kebutuhan pengguna.
\end{abstract}

Kata kunci: website, pelatihan, promosi, produk unggulan

\section{PENDAHULUAN}

Internet memberikan peluang tambahan untuk memperbaiki citra dan reputasi perusahaan atau organisasi (Prayudi, 2013). Perkembangan tersebut, menuntut pihak-pihak manajemen organisasi lebih bertanggung jawab serta responsive terhadap kebutuhan publik. Selain itu, internet merupakan sebuah media dengan segala karakteristiknya. Internet memiliki teknologi, cara menggunakan, lingkup pelayanan, dan isi serta image tersendiri (Kurbalija, 2011). Perkembangan ilmu pengetahuan dan perkembangan teknologi informasi khusus internet semakin bertambah pesat, terutama penggunaannya dalam bidang komunikasi dan penyebaran informasi. Kemajuan teknologi informasi dan komunikasi berdampak pada kemudahan dan kecepatan dalam penyebaran suatu informasi yang salah satu contohnya melalui media internet. 
Salah satu produk dari perkembangan teknologi informasi pada media internet adalah Website dan email. Website merupakan kumpulan dari halaman-halaman situs yang terangkum dalam sebuah domain atau sub domain pada world wide web (www) di internet. Website dapat sebagai sarana publikasi informasi baik itu oleh individu, sekolah, pedagang, instansi pemerintah, dan termasuk suatu organisasi (Ayuningtyas, 2017). Suatu organisasi sudah seharusnya memiliki sebuah website sebagai sarana sosialisasi dan menyebarkan informasi. Website bagi sebuah organisasi merupakan identitas penting (Herdiana, 2017).

Patuk (Bahasa Jawa: Pathuk) adalah sebuah kecamatan di Kabupaten Gunung Kidul, Provinsi Daerah Istimewa Yogyakarta, Indonesia. Kecamatan ini berjarak sekitar $16 \mathrm{Km}$ dari Wonosari, ibu kota Kabupaten Gunungkidul ke arah barat laut melalui jalan nasional ruas Kota Yogyakarta-Wonosari. Pusat pemerintahannya berada di Desa Patuk. Kecamatan Patuk terdiri dari 11 desa yaitu Beji, Bunder, Nglanggeran, Nglegi, Ngoro-oro, Patuk, Pengkok, Putat, Salam, Semoyo dan Terbah. Masing-masing desa tersebut mempunyai usaha mikro, kecil dan menengah (UMKM) dengan berbagai macam produk unggulan dan pariwisata (Yudanto et al., 2019). Setiap desa mempunyai potensi yang berbeda-beda yang bisa dijadikan produk unggulan atau pariwisata. Melalui kelompok-kelompok yang ada di masing-masing desa ini mereka terus melakukan pengembangan potensi desanya. Sejalan dengan misi pemerintah dalam menggalakkan nasionalisme terhadap produk-produk UMKM tanah air, saat ini sedang gencarnya penjualan berbasis daring (Sisfor, 2019; Agusetyaningrum et al., 2016; Setyowardhani et al., 2019). Potensi yang dimiliki oleh desa-desa di kecamatan Patuk ini cukup bervariasi (Nana, 2015). Misalnya desa Ngoro-oro mengembangkan makanan ringan seperti kembang goyang, mangleng, keripik talas, peyek dan lain lain. Desa Patuk dengan kerajinan logamnya, desa terbah dengan potensi pisang, desa nglanggeran dengan potensi coklat dan tempat wisatanya dan lain sebagainya.

Pengembangan potensi 11 desa di kecamatan Patuk ini sudah semakin maju. Hal ini tidak terlepas dari peran Badan Kerjasama Antar Desa (BKAD) Kecamatan Patuk. Kegiatan kelompok UMKM di Kecamatan Patuk ini dikoordinasikan dan dibina oleh BKAD Kecamatan Patuk tersebut (Indrianingsih et al., 2020). Baik dari segi pembinaan keterampilannya maupun pinjaman lunak untuk mengembangkan UMKM tersebut. Di Kecamatan Patuk sebenarnya sudah ada Sistem Informasi Desa (SID) yang berisi informasi-informasi tentang desa-desa yang ada ada di kecamatan Patuk berikut potensi yang dimilikinya. Akan tetapi SID ini belum dijalankan dengan baik karena keterbatasan keterampilan dan sumber daya yang ada . Tampilan SID kecamatan Patuk dapat dilihat pada Gambar 1.

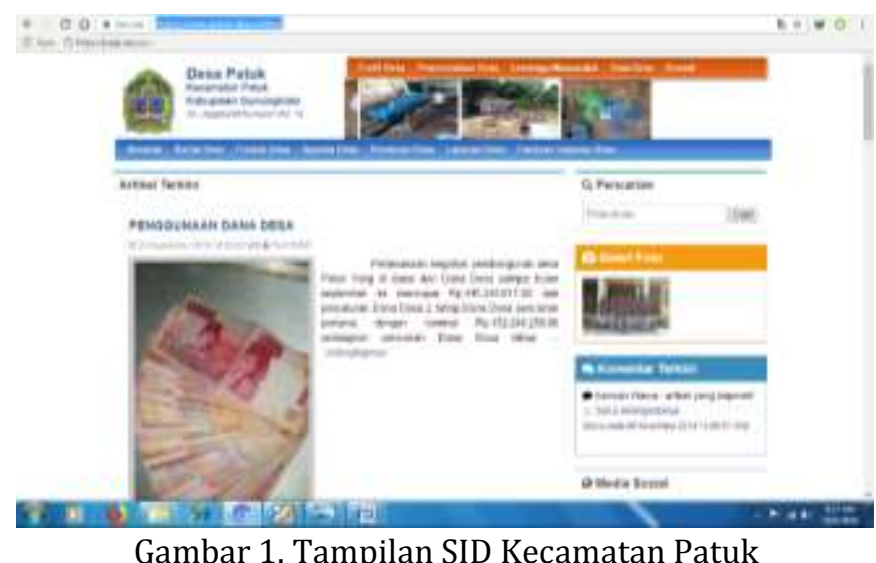

Masalah yang akan diselesaikan oleh Tim Pengabdian Kepada Masyarakat ini antara lain perlunya meningkatkan kesadaran dan pemahaman bersama pada aparatur kecamatan, BKAD dan UMKM tentang pentingnya promosi produk dan pariwisata serta pemafaatan internet khususnya melalui Website dalam upaya mengembangkan promosi produk unggulan desa yang ada di Kecamatan Patuk dalam mendukung Pariwisata di Gunungkidul. Selanjutnya diharapkan dapat menumbuh kembangkan ketrampilan dan kemampuan yang dimiliki oleh aparatur 
kecamatan, BKAD dan UMKM dalam mempromosikan produk unggulan desanya serta mengoperasionalkan penggunaan Website. Website promosi produk unggulan desa ini merupakan hasil dari penelitian Tim Pengabdian Kepada Masyarakat yang telah dilakukan sebelumnya.

Beberapa hal di atas menjadi latar belakang penulis untuk mengangkat produk unggulan desa agar dikenal masyarakat luas melalui pelatihan Website promosi Kecamatan Patuk. Adapun manfaat adanya pelatihan ini antara lain:

1. Setelah mengikuti pelatihan, aparatur Kecamatan, BKAD dan UMKM dapat memahami pentingnya promosi produk.

2. Meningkatkannya pengetahuan dan ketrampilan para pelaku UMKM di Kecamatan Patuk dalam operasionalisasi internet (Website) sebagai alat atau media promosinya.

Para aparatur Kecamatan, BKAD dan UMKM di Patuk dalam melakukan pengelolaan dan pengisan atau peng-upload-an materi pada Website secara rutin apabila ada perubahan pada produk unggulan dan pariwisata di Kecamatan Patuk.

\section{METODE}

Pelatihan Website promosi Kecamatan Patuk untuk mengoptimalkan produk unggulan desa merupakan program yang ditujukan kepada masyarakat desa di Kecamatan Patuk khususnya petugas BKAD dan admin SID di masing-masing desa untuk meningkatkan ketrampilan para pelaku dalam menggunakan Website sebagai sarana promosi produk unggulan di masing-masing desanya. Metode yang digunakan dalam upaya mencapai tujuan dalam pengabdian ini adalah melalui beberapa metode yaitu:

1. Metode sosialisasi yang bertujuan untuk memberikan pemahaman tentang arti pentingnyaWebsite dalam era digital informasi global untuk mempromosikan produk unggulan masing-masing desa yang ada di Kecamatan Patuk Gunungkidul sehingga bermanfaat bagi pengembangan kehidupan sosial, budaya, dan ekonomi masyarakat.

2. Metode pelatihan bertujuan untuk meningkatkan pengetahuan dan ketrampilan para pelaku UMKM di Kecamatan Patuk dalam operasionalisasi internet (Website) sebagai alat atau media promosinya.

3. Metode praktek lapangan, yakni praktek mengoperasionalkan Wesbite produk UMKM.

4. Metode pendampingan kepada para aparatur Kecamatan, BKAD dan UMKM di Patuk dalam realisasi pengisan atau peng-upload-an materi pada Website.

Dalam kegiatan ini, ada beberapa prosedur kerja yang dilakukan oleh Tim Pelaksana PKM, yaitu:

1. Tim PKM menyusun rencana kerja yang tersistem dalam rancangan pelatihan pengelolaan Website sebagai media promosi .

2. Tim PKM secara bersama-sama melakukan sosialisasi tahap 1 tentang pentingnya pemanfaatan internet bagi UKMK atau desa kepada para aparatur kecamatan atau BKAD yang ditunjuk oleh kecamatan sebagai administrator dalam Website Kec. Patuk.

3. Tim PKM melaksanakan pelatihan serta pendampingan dalam pembuatan atau pengupload-an informasi di internet.

Pada akhir pelatihan Website dilaksanakan penyebaran angket keterlaksanaan program pelatihan penggunaan Website promosi bagi admin Kecamatan Patuk untuk optimalisasi pengenalan produk unggulan desa.

\section{HASIL DAN PEMBAHASAN}

Hasil dari pelaksanaan program pelatihan Website promosi untuk mengoptimalkan pengenalan produk unggulan desa di Kecamatan Patuk adalah sebagai berikut: 
1. Tim PKM menyusun manual book dari penggunaan Website promosi, khususnya untuk admin atau pengelola Website. Dimana di dalam manual book tersebut memuat beberapa petunjuk penggunaan Website seperti cara melakukan registrasi pengelola, penambahan data atau pengelola, penghapusan data, perubahan data. Adapun rincian menu yang dapat digunakan untuk mengelola produk dan obyek wisata di masingmasing desa dapat dilihat pada Tabel 1.

Tabel 1. Nama dan Fungsi Menu Website Bagian Admin






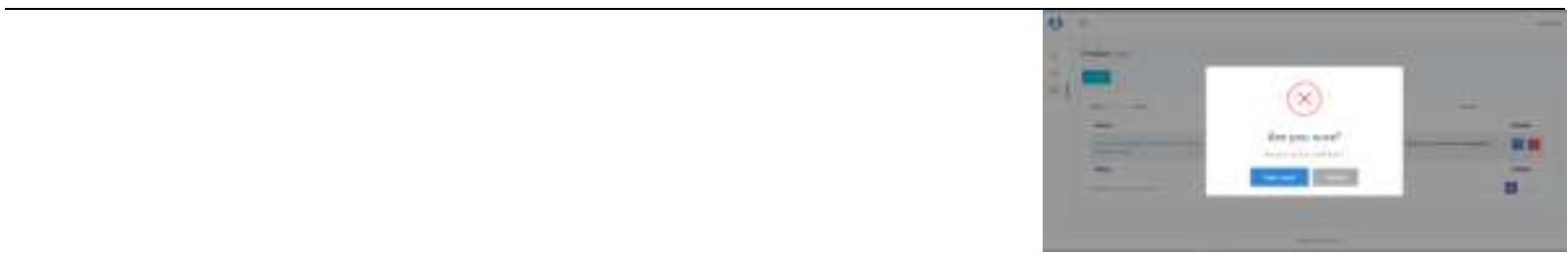

\begin{tabular}{ll}
\hline Pengelola & Untuk \\
& menambahkan/mengubah/menghapus
\end{tabular}

pengelola data pada usaha

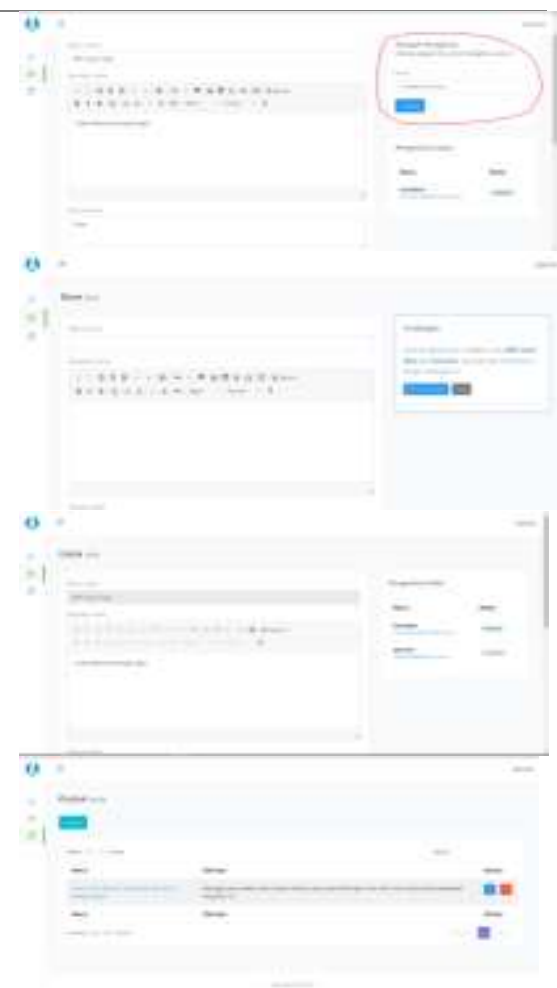

Untuk mendukung penyelarasan materi pelatihan dan praktik, Tim PKM memberikan alat hibah berbasis Program Komputer yaitu Website yang dapat diakses di www.jelajahipatuk.com/admin guna promosi produk unggulan dan obyek wisata setiap desa di Kecamatan Patuk dan data pendukung yang telah didokumentasikan ke penyimpanan eksternal berupa Flashdisk yang telah dibagikan ke masing-masing desa (operator Sistem Informasi Desa).

Hasil pelatihan Website promosi produk UMKM dan obyek wisata ini berupa ketrampilan pengelola SID di masing-masing desa dalam mengoperasikan Website Promosi (www.jelajahipatuk.com/admin). Setelah peserta pelatihan melakukan praktik pada menu-menu admin yang terdapat di Website, peserta diminta mengisi angket keterlaksanaan program pelatihan penggunaan Website promosi bagi admin Kecamatan Patuk untuk optimalisasi pengenalan produk unggulan desa. Nilai rata-rata presentase digunakan untuk menentukan status kelayakan Website Promosi dengan siklus ideal dengan acuan interval seperti yang terilihat pada Tabel 2 .

Tabel 2. Interval skor Penilaian

\begin{tabular}{cc}
\hline Nilai rata rata & Status \\
\hline $0-20 \%$ & Tidak Baik \\
$21-40 \%$ & Kurang baik \\
$41-60 \%$ & Cukup Baik \\
$61-80 \%$ & Baik \\
$81-100 \%$ & Sangat Baik \\
\hline
\end{tabular}


Diperoleh hasil 87,36 \% dimana berdasarkan Tabel 2 nilai tersebut masuk dalam kategori "Sangat Baik". Sehingga dapat dinyatakan bahwa media promosi berbasis Website untuk promosi produk UMKM dan obyek wisata ini telah memenuhi kebutuhan admin yaitu pengelola (requirement), memenuhi kebutuhan semua pihak yang berkepentingan, dan Website promosi dapat berjalan dengan sangat baik.

\section{KESIMPULAN}

Kegiatan pengabdian kepada masyarakat ini dapat terselenggara dengan baik dan mampu memberikan dampak sesuai yang diharapkan. Hal ini terlihat dari para pengguna Website Promosi yaitu admin pengelola produk UMKM dan obyek wisata di 11 Desa Kecamatan Patuk Gunungkidul dapat mengoperasikan semua menu yang ada. Selain itu, berdasarkan uji kelayakan Website promosi pada saat pelatihan kepada setiap perwakilan di 11 Desa Kecamatan Patuk diperoleh 87,36 \%, sehingga dapat dinyatakan bahwa media promosi berbasis Website untuk promosi produk UMKM dan obyek wisata ini telah memenuhi kebutuhan admin yaitu pengelola (requirement), memenuhi kebutuhan semua pihak yang berkepentingan, dan Website promosi dapat berjalan dengan sangat baik.

\section{UCAPAN TERIMA KASIH}

Tim PKM STTA Yogyakarta yang terdiri dari Dosen Prodi Teknik Informatika dan Teknik Industri mengucapkan terima kasih kepada Kabupaten Gunungkidul khususnya Kecamatan Patuk yang telah bekerja sama untuk kelancaran kegiatan pelatihan ini dan STTA Yogyakarta yang telah memberikan pendanaan Hibah Pengabdian Multidisiplin tahun 2019.

\section{DAFTAR PUSTAKA}

P. (2013). Manajemen Isu dan Tantangan Masa Depan: Pendekatan Public Relations. Jurnal ILMU KOMUNIKASI, 4(1), 25-39. https://doi.org/10.24002/jik.v4i1.229

Agusetyaningrum, V., Mawardi, M., \& Pangestuti, E. (2016). Strategi Pengembangan Usaha Kecil dan Menengah (UKM) Untuk Meningkatkan Citra Kota Malang Sebagai Destinasi Wisata Kuliner (Studi Pada Ukm Berbasis Kuliner Kota Malang). Jurnal Administrasi Bisnis S1 Universitas Brawijaya, 38(2), 105-111.

Ayuningtyas, A. (2017). Sistem Pemasaran Produk Berbasis Web Pada Koperasi. III.

Herdiana. (2017). Pengelolaan Website Sebagai Media Informasi Publik Pada Bagian Humas Dan Informasi Pemerintah Kota Pekanbaru. Journal of Chemical Information and Modeling, 53(9), 1689-1699. https://doi.org/10.1017/CB09781107415324.004

Indrianingsih, Y., Ayuningtyas, A., \& Mauidzoh, U. (2020). y \% ̈̈ \&' ̈̈ \& ( ̈̈. Angkasa, 12(1), 79 88.

Kurbalija, J. (2011). Sebuah Pengantar Tentang Tata Kelola Internet. 228.

Nana. (2015). Kondisi Umum. Retrieved Maret 2, 2020, from https://gunungkidulkab.go.id/D74db63a914e6fb0f4445120c6fa44e6a-NR-100-0.html.

Setyowardhani, H., Susanti, H., \& Riyanto. (2019). Optimalisasi Media Sosial sebagai Alat Promosi untuk Desa Wisata Lebakmuncang. Dinamisia: Jurnal Pengabdian Kepada Masyarakat, 3, 19-26. https://doi.org/10.31849/dinamisia.v3i2.2848

Sisfor, R. S. (2019). Perancangan dan Implementasi Sistem E-Commerce pada UMKM Batik di Kabupaten Jombang. Dinamisia: Jurnal Pengabdian Kepada Masyarakat, 3(1), 36-43. https://doi.org/10.31849/dinamisia.v3i1.2061

Yudanto, A. A., Raharjo, T., \& Ubed, R. S. (2019). Pendampingan Pengembangan Produk Unggulan Kawasan Perdesaan Pada Usaha Berbasis Komunitas Desa Cibogo. Dinamisia: Jurnal Pengabdian Kepada Masyarakat, 2(2), 161-166. https://doi.org/10.31849/dinamisia.v2i2.2297 